\title{
Experimental Study the Effect of Tool Design on the Mechanical Properties of Bobbin Friction Stir Welded 6061-T6 Aluminum Alloy
}

\author{
Samir Ali Amin* Mohannad Yousif Hanna** \\ Alhamza Farooq Mohamed*** \\ ***,*** Department of Mechanical Engineering/ University of Technology \\ *Email:alrabiee2002@yahoo.com \\ ** Email: mohannad_hanna@yahoo.com \\ ***Email: alhamza88f@yahoo.com
}

(Received 27 September 2017; accepted 30 January 2018)

https://doi.org/10.22153/kej.2018.01.003

\begin{abstract}
Bobbin friction stir welding (BFSW) is a variant of the conventional friction stir welding (CFSW); it can weld the upper and lower surface of the work-piece in the same pass. This technique involves the bonding of materials without melting. In this work, the influence of tool design on the mechanical properties of welding joints of 6061-T6 aluminum alloy with $6.25 \mathrm{~mm}$ thickness produced by FSW bobbin tools was investigated and the best bobbin tool design was determined. Five different probe shapes (threaded straight cylindrical, straight cylindrical with 3 flat surfaces, straight cylindrical with 4 flat surfaces, threaded straight cylindrical with 3 flat surface and threaded straight cylindrical with 4 flat surfaces) with various dimensions of the tool (shoulders and pin) were used to create the welding joints. The direction of the welding process was perpendicular to the rolling direction for aluminum plates. Tensile and bending tests were performed to select the right design of the bobbin tools, which gave superior mechanical properties of the welded zone. The tool of straight cylindrical with four flats, $8 \mathrm{~mm}$ probe and $24 \mathrm{~mm}$ shoulders diameter gave better tensile strength (193 MPa), elongation $(6.1 \%)$, bending force $(5.7 \mathrm{KN})$, and welding efficiency $(65.4 \%)$ according to tensile strength.
\end{abstract}

Keywords: Bobbin FSW, Bobbin tool design, AA6061-T6, Mechanical properties.

\section{Introduction}

Friction stir welding (FSW) is a solid-state bonding process feigned in 1991, at The Welding Institute. FSW is a substitutional welding technique to conventional fusion welding. The joint is produced via a non-consumed refractory cylindrical rotating tool, mechanically passed through the material of the work-piece. The friction between wear-resistant tool and the substrate generates heat. Because the frictional heat is generated, the stirred material is softened and mixed [1]. Under the shoulder of the tool, the material flows are like the forging operation, whereas the flows of material surrounding the tool probe are similar to the extrusion operation [2]. This technique is used for joining aluminum alloys, although other materials are possible inclusive dissimilar materials. The welding technology, patented via Thomas et al. [3], has been used to automotive, shipbuilding, and aerospace industries [4].

The usage of a bobbin friction stir welding (BFSW) tool, see figure (1), presented the capability to outdo of the limitations faced in the CFSW [5]. This technique uses a tool consisting of a probe and double shoulders. The tool shoulders contact with both the lower and upper substrate surface. It can be referred to that the aluminum alloy plates with higher thickness could be joined 
by friction stir welding process; nevertheless, the next information show why it's eligible to also use the BFSW-tool for this intent. Using double shoulders able to balance the down forces created via the tool with individual shoulders and so revokes the resulted axial down force. As well, the peril of root defect is basically removed with this type of tool design. Due to the uniform heat input distribution, the bobbin FSW process exhibits good welded joints with lest distortions compared to the CFSW process. In addition, the bobbin friction stir welding technique could superfast the transverse speed and raise the efficiency of the welding process in substrate with thicker section [6].

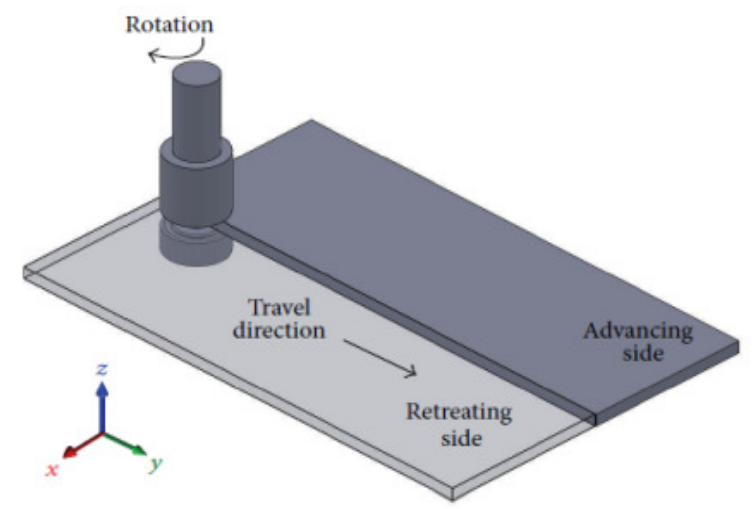

Fig. 1. Schematic diagram of BFSW [4].

The design of a single shoulder tool (CFSW) has been focused by numerous researches, while the bobbin tool has had so less studies solicitude. T. Neuman et al. [7] have reported that the tool with threaded cylindrical probe and the tool with threaded cylindrical probe having 3 flats enable to create satisfying welding outcomes, since there is no formed internal defect. The above tools were utilized to weld AA2024-T351 with $4 \mathrm{~mm}$ thickness. M. K. Sued et al. [8] investigated the influence of probe geometry on the mechanical properties and microstructure development of 6082-T6 aluminum alloy joining by BFSW and developed a model relating the basic physics to the manufacturing process in FSW bobbin-tool. W. M. Thomas et al. [9] notified complete permeation BFS welded joints, free of penetration shortage, and root flaws. For bobbin tool, two shoulders supply appropriate heat generation from both the surfaces of the substrate, and the inclusion of reactive forces within the tool itself denotes that compressive distortion (Squashing) of the pin does not take place. To promote the swept soft material volume via a tapered probe; investigators exhorted 3 flat surfaces feature to be used on the probe. This tool geometry was applied to weld $12 \%$ chromium alloy steel $8 \mathrm{~mm}$ thick, and produced a successful good weld [10]. A tapered probe with three flats allows to reduce the diameter of the bottom shoulder that participates in lowering the bending moment and torque. A lot of other researchers studied the understanding of the influence of welding process parameters on the material flow characteristics, microstructure evolution and mechanical properties of the joint line welded by BFSW [11-15].

The aim of this paper is first to design and manufacture a new fixed type bobbin tool, to show the effect of changing the diameters of the pin and shoulders of this tool, and then select the best design of this bobbin tool depending on the mechanical properties (elongation, tensile strength and maximum bending force) and weld joint quality for aluminum alloy (6061-T6) welded by bobbin FSW.

\section{Experimental Work \\ 2.1 Selection of Material and Specimens Preparation}

In this work the base metal was aluminum alloy AA6061-T6, which is (Al-Mg-Si) grade alloy of 6xxx series. The plate of AA6061-T6 was cut into the desired size $(200 \mathrm{~mm} \times 100 \mathrm{~mm} \times 6.25 \mathrm{~mm})$ via a power saw cutting machine, and the edge of the piece was ground to secure that there is no chasm exists between the two substrates that make the desired butt joint design. The chemical composition of the work-piece plate was obtained via a spectra device available in Special Institute for Engineering Industries (SIEI), as presented in table (1). The mechanical properties were performed for this plate in strength laboratory in Mechanical Engineering Department, University of Technology and are given in table (2).

Table 1,

Standard and actual chemical compositions of aluminum alloy 6061-T6

\begin{tabular}{|c|c|c|c|c|c|c|c|c|c|c|}
\hline \multirow[b]{2}{*}{ Wt. \% } & \multirow[b]{2}{*}{ Si } & \multirow[b]{2}{*}{$\mathbf{F e}$} & \multirow[b]{2}{*}{$\mathbf{C u}$} & \multicolumn{2}{|c|}{ Element } & \multirow[b]{2}{*}{$\mathrm{Cr}$} & \multirow[b]{2}{*}{$\mathrm{Zn}$} & \multirow[b]{2}{*}{$\mathbf{T i}$} & \multirow[b]{2}{*}{$\mathrm{Ni}$} & \multirow[b]{2}{*}{ Al } \\
\hline & & & & Mn & Mg & & & & & \\
\hline Standard[16] & $0.4-0.8$ & $<0.7$ & $0.15-0.4$ & $<0.15$ & $0.8-1.2$ & $0.04-0.35$ & $<0.0 .25$ & $<0.7$ & $<0.05$ & Bal. \\
\hline Actual & 0.6 & 0.57 & 0.26 & 0.10 & 0.89 & 0.18 & 0.037 & 0.054 & 0.003 & Bal. \\
\hline
\end{tabular}


Table 2,

Standard and actual mechanical properties of aluminum alloy 6061-T6

\begin{tabular}{llll}
\hline & Yield stress(MPa) & Ultimate tensile stress(MPa) & Elongation (\%) \\
\hline Standard Value [16] & $\geq 240$ & $\geq 290$ & $\geq 10$ \\
\hline Actual Value & 244.5 & 295 & 11.5 \\
\hline
\end{tabular}

\subsection{Design and Manufacturing of Bobbin Tools}

There are two significant domains of bobbin friction stir welding tool design: selection of tool material and geometry (features and dimensions).

There are significant influences to the tool pending welding: high temperature, abrasive wear and dynamic influences. Therefore, the good materials of the tool have the following characteristics: good wear resistance, high temperature strength, temper resistance and good toughness. In the FSW of aluminum alloys, the wear of the welding tool is not so much. Tool materials like tool steel can be utilized for FSW [2]. Hot-work tool steel (H13) is the most ordinarily utilized material, easy availability and machinability, wear resistance, thermal fatigue resistance, essentially for copper and aluminum [17]. The tools in this work were fabricated from a hot-work tool steel (H13).

In order to select a best design, five various tools with probe profiles (threaded straight cylindrical pin, straight cylindrical with three flat surfaces, straight cylindrical with four flat surfaces, threaded straight cylindrical with three flat surfaces and threaded straight cylindrical with four flat surfaces) and flat shoulders with different diameters in all cases were utilized, see figure (2). The bobbin friction stir welding tools were fabricated by conventional lathe and milling machines. The tool heat treatment comprises heating the tool alloy to $1070^{\circ} \mathrm{C}$ about $30 \mathrm{~min}$ and then air cooling to room temperature, followed by two tempering steps at $550^{\circ} \mathrm{C}$ and $500^{\circ} \mathrm{C}$, respectively. Then, the tool was air cooled to room temperature in each step, resulting in a hardness about 49 HRC $[18,19]$. All details of designed and fabricated bobbin tools are given in table (3), including pin diameter, flat side width, pitch of the thread, shoulder diameter, feature of shoulder surface and shoulders gap.

\subsection{Welding Procedure}

The substrate has to be clamped rigidly at a predetermined location onto a fixing framework, see figure (3). Bobbin welding is started by driving onto the edge of the work-piece and then the workpiece is moved against the pin. The experiments were completed using a one pass normal to the plate rolling direction (longitudinal). At first, slow travel speed till plastic deformation occurs, followed by acceleration of the welding speed to the required speed, and then the tool moves over the joint line at a constant travel speed. The material in front of the rotating tool probe is plastically distorted and stirred back to the trail edge of the tool pin in the welding [20]. The used welding parameters were selected according to the information from the previous research in this field and the practical expertise. These parameters are given in table (4). Classic milling machine model (FU 251) was used to complete the welding process.

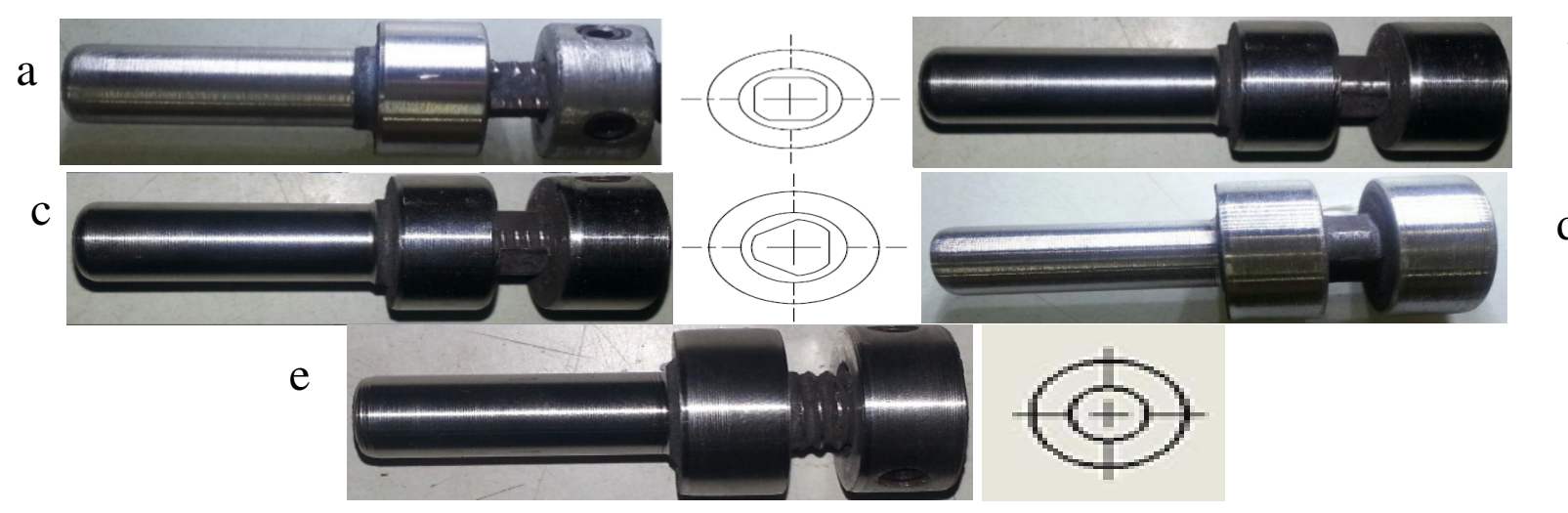

Fig. 2. a) Threaded straight cylindrical with 4 flat surfaces, b) Straight cylindrical with 4 flat surfaces, c) Threaded straight cylindrical with 3 flat surfaces, d) Straight cylindrical with 3 flat surfaces, e) Threaded straight cylindrical pin. 
Table 3,

BFSW tools (dimensions and features)

\begin{tabular}{|c|c|c|c|c|c|c|c|}
\hline $\begin{array}{l}\text { Description } \\
\text { of the probe }\end{array}$ & $\begin{array}{l}\text { BFSW } \\
\text { Tool No. }\end{array}$ & $\begin{array}{l}\text { pin } \\
\text { diameter } \\
\text { (d) }(\mathrm{mm})\end{array}$ & $\begin{array}{l}\text { Flat side } \\
\text { width }(\mathrm{mm})\end{array}$ & $\begin{array}{l}\text { Pitch of } \\
\text { thread } \\
(\mathrm{mm})\end{array}$ & $\begin{array}{l}\text { Shoulder } \\
\text { Diameter } \\
\text { (D) }(\mathbf{m m})\end{array}$ & $\begin{array}{l}\text { Feature } \\
\text { of } \\
\text { shoulder }\end{array}$ & $\begin{array}{l}\text { Gap of } \\
\text { shoulders } \\
(\mathrm{mm})\end{array}$ \\
\hline $\begin{array}{l}\text { Straight threaded } \\
\text { cylindrical }\end{array}$ & BT-1 & 10 & - & 1.5 & $\begin{array}{l}20 \\
(2 d) \\
\end{array}$ & Flat & 6.25 \\
\hline $\begin{array}{l}\text { Straight threaded } \\
\text { cylindrical }\end{array}$ & BT-2 & 10 & 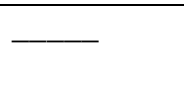 & 1 & $\begin{array}{l}20 \\
(2 d)\end{array}$ & Flat & 6.25 \\
\hline $\begin{array}{l}\text { Straight cylindrical }+ \\
3 \text { flats }\end{array}$ & BT-3 & 10 & 0.67 & 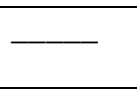 & $\begin{array}{l}20 \\
(2 d) \\
\end{array}$ & Flat & 6.25 \\
\hline $\begin{array}{l}\text { Straight cylindrical }+ \\
4 \text { flats }\end{array}$ & BT-4 & 10 & 0.67 & - & $\begin{array}{l}20 \\
(2 \mathrm{~d})\end{array}$ & Flat & 6.25 \\
\hline $\begin{array}{l}\text { Straight threaded } \\
\text { cylindrical+ } 3 \text { flats }\end{array}$ & BT-5 & 10 & 0.67 & 1 & $\begin{array}{l}20 \\
(2 d)\end{array}$ & Flat & 6.25 \\
\hline $\begin{array}{l}\text { Straight threaded } \\
\text { cylindrical+ } 4 \text { flats }\end{array}$ & BT-6 & 10 & 0.67 & 1 & $\begin{array}{l}20 \\
(2 d)\end{array}$ & Flat & 6.25 \\
\hline $\begin{array}{l}\text { Straight threaded } \\
\text { cylindrical }\end{array}$ & BT-7 & 8 & 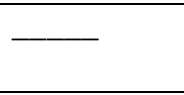 & 1 & $\begin{array}{l}16 \\
(2 d)\end{array}$ & Flat & 6.25 \\
\hline $\begin{array}{l}\text { Straight cylindrical }+ \\
3 \text { flats }\end{array}$ & BT-8 & 8 & 0.5 & 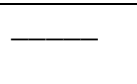 & $\begin{array}{l}16 \\
(2 \mathrm{~d})\end{array}$ & Flat & 6.25 \\
\hline $\begin{array}{l}\text { Straight cylindrical }+ \\
4 \text { flats }\end{array}$ & BT-9 & 8 & 0.5 & - & $\begin{array}{l}16 \\
(2 d)\end{array}$ & Flat & 6.25 \\
\hline $\begin{array}{l}\text { Straight threaded } \\
\text { cylindrical+ } 3 \text { flats }\end{array}$ & BT-10 & 8 & 0.5 & 1 & $\begin{array}{l}16 \\
(2 d)\end{array}$ & Flat & 6.25 \\
\hline $\begin{array}{l}\text { Straight threaded } \\
\text { cylindrical+ } 4 \text { flats }\end{array}$ & BT-11 & 8 & 0.5 & 1 & $\begin{array}{l}16 \\
(2 d)\end{array}$ & Flat & 6.25 \\
\hline $\begin{array}{l}\text { Straight threaded } \\
\text { cylindrical }\end{array}$ & BT-12 & 12 & 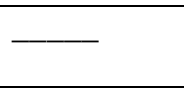 & 1.5 & $\begin{array}{l}24 \\
(2 d)\end{array}$ & Flat & 6.25 \\
\hline $\begin{array}{l}\text { Straight cylindrical }+ \\
3 \text { flats }\end{array}$ & BT-13 & 12 & 0.8 & $\ldots$ & $\begin{array}{l}24 \\
(2 d)\end{array}$ & Flat & 6.25 \\
\hline $\begin{array}{l}\text { Straight cylindrical }+ \\
4 \text { flats }\end{array}$ & BT-14 & 12 & 0.8 & - & $\begin{array}{l}24 \\
(2 d)\end{array}$ & Flat & 6.25 \\
\hline $\begin{array}{l}\text { Straight threaded } \\
\text { cylindrical+ } 3 \text { flats }\end{array}$ & BT-15 & 12 & 0.8 & 1.5 & $\begin{array}{l}24 \\
(2 d)\end{array}$ & Flat & 6.25 \\
\hline $\begin{array}{l}\text { Straight threaded } \\
\text { cylindrical+ } 4 \text { flats }\end{array}$ & BT-16 & 12 & 0.8 & 1.5 & $\begin{array}{l}24 \\
(2 \mathrm{~d}) \\
\end{array}$ & Flat & 6.25 \\
\hline $\begin{array}{l}\text { Straight cylindrical + } \\
4 \text { flats }\end{array}$ & BT-17 & 8 & 0.5 & & $\begin{array}{l}20 \\
(2.5 \mathrm{~d})\end{array}$ & Flat & 6.25 \\
\hline $\begin{array}{l}\text { Straight cylindrical }+ \\
4 \text { flats }\end{array}$ & BT-18 & 10 & 0.67 & 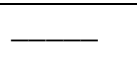 & $\begin{array}{l}25 \\
(2.5 \mathrm{~d})\end{array}$ & Flat & 6.25 \\
\hline $\begin{array}{l}\text { Straight cylindrical }+ \\
4 \text { flats }\end{array}$ & BT-19 & 12 & 0.8 & & $\begin{array}{l}30 \\
(2.5 \mathrm{~d})\end{array}$ & Flat & 6.25 \\
\hline $\begin{array}{l}\text { Straight cylindrical }+ \\
4 \text { flats }\end{array}$ & BT-20 & 8 & 0.5 & & $\begin{array}{l}24 \\
(3 \mathrm{~d})\end{array}$ & Flat & 6.25 \\
\hline $\begin{array}{l}\text { Straight cylindrical }+ \\
4 \text { flats }\end{array}$ & BT-21 & 8 & 0.5 & - & $\begin{array}{l}24 \\
(3 d)\end{array}$ & Flat & 6.4 \\
\hline $\begin{array}{l}\text { Straight cylindrical + } \\
4 \text { flats }\end{array}$ & BT-22 & 8 & 0.5 & $\ldots$ & $\begin{array}{l}24 \\
(3 d)\end{array}$ & Flat & 6.1 \\
\hline $\begin{array}{l}\text { Straight threaded } \\
\text { cylindrical+ } 3 \text { flats }\end{array}$ & BT-23 & 8 & 0.5 & 1 & $\begin{array}{l}24 \\
(3 d)\end{array}$ & Flat & 6.25 \\
\hline
\end{tabular}



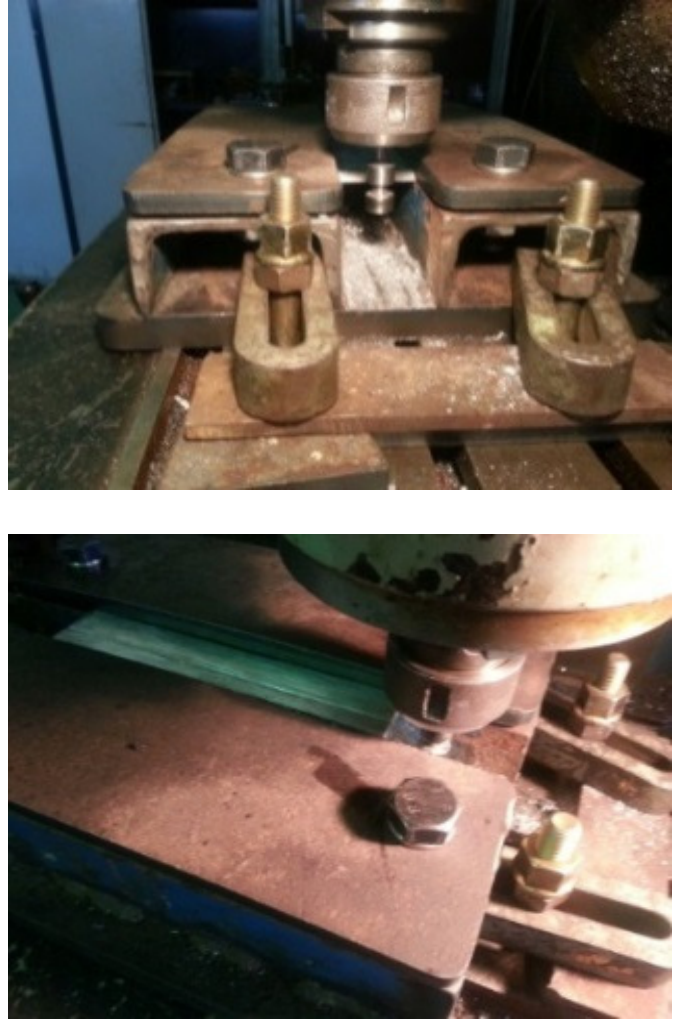

Fig. 3. Fixing framework.

Table 4,

Used Bobbin friction stir welding process

parameters

\begin{tabular}{ll}
$\begin{array}{l}\text { Tool rotational speed (spindle speed) } \\
(\mathrm{rpm})\end{array}$ & 560 \\
\hline $\begin{array}{l}\text { Welding speed (travel speed) } \\
(\mathrm{mm} / \mathrm{min})\end{array}$ & 80 \\
\hline $\begin{array}{l}\text { Dwell speed } \\
(\mathrm{mm} / \mathrm{min})\end{array}$ & manual \\
\hline $\begin{array}{l}\text { Dwell time } \\
(\mathrm{s})\end{array}$ & 40 \\
\hline
\end{tabular}

\subsection{Mechanical Tests}

Tensile test was done on specimens possessed in direction normal to the joint line to define the tensile properties of the joints for all welding experiments. The form and dimensions of the longitudinal tensile specimens according to the standard (ASTM-E8) are presented in figure (4.a). Tensile experiments were done at $1 \mathrm{~mm} / \mathrm{min}$ loading rate at room temperature using a computerized universal testing machine (Hydraulic Tunis Olsen). Then, the average value of three tested samples was taken for determining the elongation and ultimate tensile strength of each joint. Three point bending test was done to obtain the maximum bending force of the joints. The form and dimensions of the longitudinal bending sample according to the standard (ASTM-E190) are presented in figure (4.b). The bending test was done at constant loading rate $(5 \mathrm{~mm} / \mathrm{min})$ at room temperature by a universal testing machine (Hydraulic LARYEE testing machine).
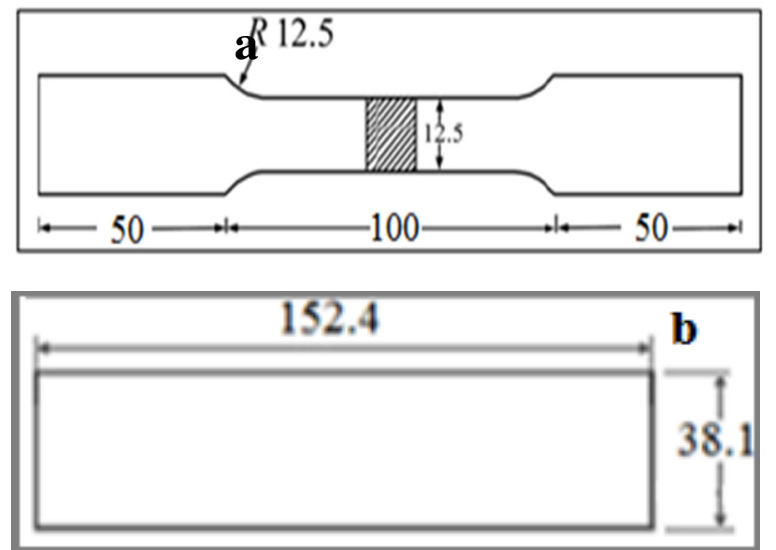

Fig. 4. a) Tensile test specimen (all dimensions in mm) (ASTM-E8), b) Bending test specimen (all dimensions in mm) (ASTM-E190M) .

\section{Experimental Results and Discussion 3.1 Visual Inspections}

The visual inspection consequences are presented in Fig. 5. These exhibit the bottom and top of each joint. Some of the welded joint had a good appearance, while other welds appeared various flaws, involving open tunnel/void, excessive flash, cutting effects and incomplete joining.

1) Open tunnel and excessive flash (figures $5 a$ and $5 b)$ : This phenomenon has not been discussed and identified its causes in the previous literature in large active area, but it can be explicated as follows. The distribution of vertical material flow was asymmetry that was evident in threaded cylindrical probe. This distribution had overflowing material on the upper substrate surface, and weld bead thinning on the lower surface. The probe threads might result much material motion toward the single surface. The potential of threaded profile potential resulting extravagant flux of vertical material has previously been specified [21]. The clockwise rotation of the tool, which is the state of present research, also the stationary vertical location of the bobbin tool prohibited the down movement of the tool. In this state, the threads existence on the probe draws up the work-piece. Thus, the swept material from the retreating side faces the soft material of the advancing side, and a complicated blending type 
engenders, see figure (6). The retreating side shown in figure $(7 \mathrm{~A})$ is pushed vertically up toward the advancing side. Therefore, the top site of the advancing side (figure 7B) is firstly filled. The smaller threads pitch will possess minimal helix angle, thus minimizing the transportation of vertical material and the flash defect, see figure (7). 2) Cutting effect (figure 5c): In this state, the plates were softened and cut via the bobbin tool and no welding took place. This was occurred when the diameter of the pin was $12 \mathrm{~mm}$ (about twice thickness of substrate) BT (12-16). The reason of this case is that the amount of heat input was not enough. The amount of heat generated is not significant to produce a good mixing for soft material flow and occur a dynamic recrystallization compared to the volume of the material was stirred. For (BT-19) design, the welding was successful, because the diameter of the shoulders was bigger; this means the heat input was significant to produce free defect welding.

3) Incomplete joints/voids/flash defect (figures $5 \mathrm{~d}$ to $5 \mathrm{~g}$ ): With gap's variation, there are changes in the semblance of welding line. When the bobbin tool (BT-21) has a gap of $6.4 \mathrm{~mm}$, which is higher than the upper allowable limit of plate thickness $(6.25 \mathrm{~mm})$ due to the difficulty in filling and coalescing the stir zone. Another case was the tool (BT-22) having a gap of $6.1 \mathrm{~mm}$. At the top surface, there was only a slight of flash, while at the bottom surface there was an excessive flash/ scraping and consequent decrease in thickness.

Several welding joints were unacceptable, because there were flash and voids in the joint line and the other joints were incomplete. These defects are not dependent only on the pin geometry (shape and dimension). Other variables can cause these defects, e.g. bad tool fabrication, substrate condition (flatness variation), and support/clamp setting, see figure (8).

Also, the failed outcomes possess partnership to how explicate the acceptable welding joints. It is submitted that the sundry influences participate to acceptable welds. The stirred material needs to have horizontal and vertical flow; the flow movement produces by the tool features. Thus, threads create vertical flow motion [21,22] and flats produce horizontal movement [23]. Hence, the tools (threaded cylindrical with $3 / 4$ flats), which comprise these profiles, achieved properly. Tools that own flats only, such as (straight cylindrical with $3 / 4$ flats), are also capable to create sound welds. Since the used plate here was not thick, it is suggested that the fit gap between the shoulders of the tool and substrate thickness equips with a vertical motion flow element of soft material. Thus, whereas flat faces might not produce the movement of vertical flow, these features do not counter it [8].
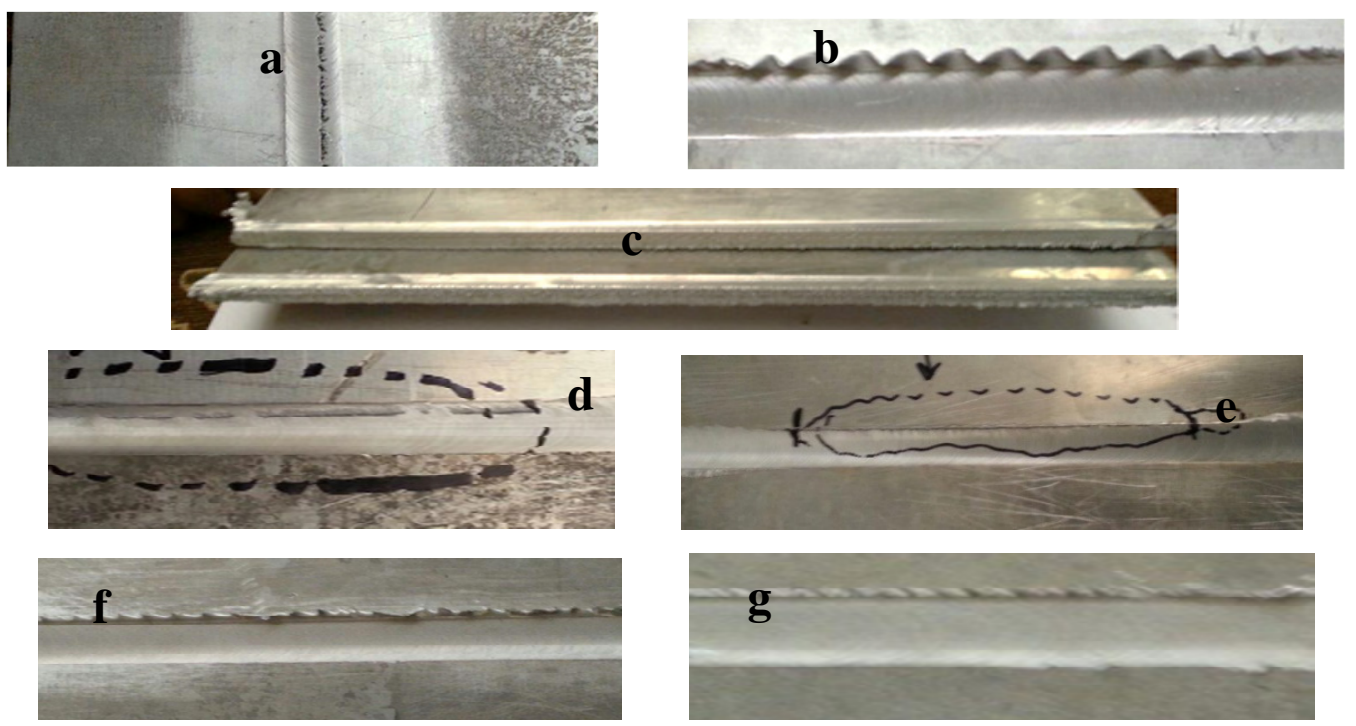

Fig. 5. a) Open tunnel defect/ lower surface (BT-1), b) Excessive flash defect/ upper surface (TB-1), c) Cutting effect (BT14), d) Void defect/ upper surface (BT-21), e) Incomplete welding/ lower surface (BT-21), f) Excessive flash defect/ lower surface (TB-22), Few flash/ upper surface (TB-22) . 


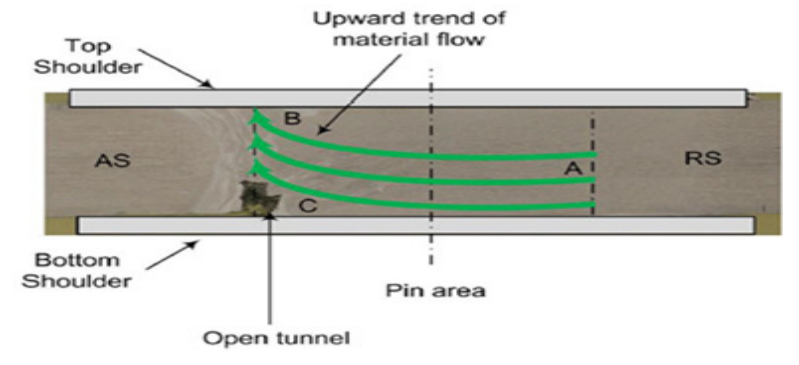

Fig. 6. Material motion around threaded probe.

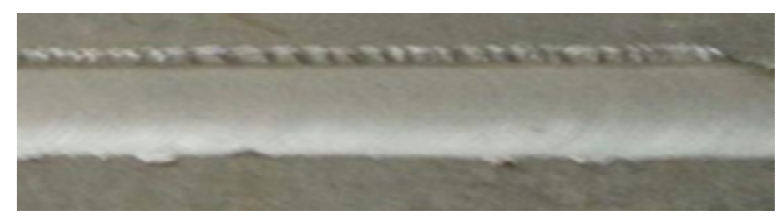

Fig. 7. Minimizing the flash defect (BT-2) .

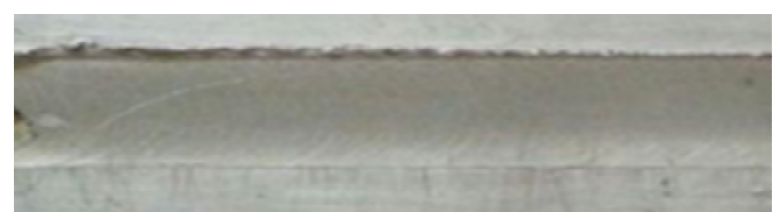

Fig. 8. Variation of flatness plate (BT-20) .

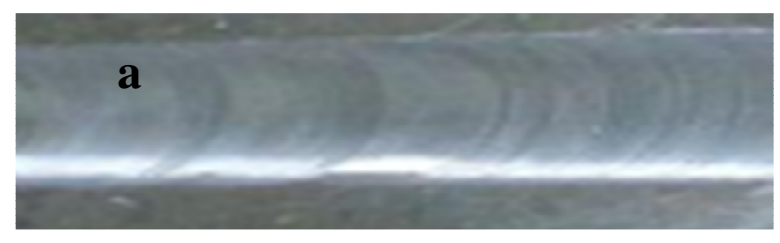

b

Fig. 9. a) Upper surface, b) Lower surface .

\subsection{Destructive Inspections}

After implementing the welding experiments, the joints were visually tested and the welds with perfect surface appearance were selected and machined according to the standard test samples for the mechanical testing. Mechanical tests were conducted to define the mechanical behavior of the weld zone and select the best probe design by the maximum welding efficiency in terms of tensile strength. Tensile and bending tests were done, and the results have been classed according to the tool probe shape. The results are listed in table (5). From these results, the best bobbin tool design for the investigation condition (substrate type, thickness, and process settings) is (BT-20), which provides superior mechanical properties, see figure (9). Since the spindle and welding speeds used in this work cannot be considered as optimum parameters, so the obtained results of the mechanical properties are not the maximum for this bobbin tool (BT-20) design.

\subsection{Effects of Used Bobbin Tool Design Features and Dimensions on Weld Quality}

The outcomes characterize specifically the functional effects, for example, the thread on tool probe. The following duty is to establish a systematic explication for the causality by tool shape and other parameters that cause weld quality influences. These are established on the interpretations (above) of the empirical clues compiled in this work, and informed via the conclusions of other research in this field.

a) Threads feature (BT1, BT6 and BT11) produces high heat input and vertical flow movement following the thread orientation. The result is harmonious with pervious studies [21, 22, and 24]. However, the point of distinction in this research is the threads on the pin cause open tunnel defect in the advanced side on the bottom surface of the substrate and lead to excessive flash. This effect can be termed a drill effect as discussed above. 
Table 5,

Results of mechanical properties tests

\begin{tabular}{|c|c|c|c|c|c|c|}
\hline Exp. No. & $\begin{array}{l}\text { Tool } \\
\text { type }\end{array}$ & $\begin{array}{l}\text { Elongation } \\
(\%)\end{array}$ & $\begin{array}{l}\text { U.T.S } \\
\text { (MPa) }\end{array}$ & $\begin{array}{l}\text { W. Eff. } \\
\%\end{array}$ & $\begin{array}{l}\mathbf{B .} \mathbf{F} \\
(\mathbf{K N})\end{array}$ & Notes \\
\hline \multicolumn{7}{|c|}{$\begin{array}{c}\mathrm{d}=10 \mathrm{~mm}, \mathrm{D}=20 \mathrm{~mm} \\
(\mathrm{D}=2 \mathrm{~d})\end{array}$} \\
\hline Test 1 & BT-1 & -------- & ------- & --------- & ------ & Open tunnel defect \\
\hline Test 2 & BT-2 & -------- & ------- & --------- & ------ & Open tunnel defect \\
\hline Test 3 & BT-3 & 3.3 & 84.5 & 28.6 & 3.88 & Acceptable appearance \\
\hline Test 4 & BT-4 & 4.1 & 105 & 35.6 & 4.9 & Acceptable appearance \\
\hline Test 5 & BT-5 & 3.52 & 87.5 & 29.7 & 4.1 & Acceptable appearance \\
\hline Test 6 & BT-6 & 2.7 & 75 & 25.4 & 2.3 & Acceptable appearance \\
\hline \multicolumn{7}{|c|}{$\begin{array}{c}\mathrm{d}=8 \mathrm{~mm}, \mathrm{D}=16 \mathrm{~mm} \\
(\mathrm{D}=\mathbf{2 d})\end{array}$} \\
\hline Test 7 & BT-7 & -------- & ------ & ------- & ----- & Open tunnel defect \\
\hline Test 8 & BT-8 & 5.15 & 95.5 & 40.8 & 5.5 & Acceptable appearance \\
\hline Test 9 & BТ-9 & 3.97 & 120 & 34.6 & 4.8 & Acceptable appearance \\
\hline Test 10 & BT-10 & 3.4 & 102 & 30.2 & 2.5 & Acceptable appearance \\
\hline Test 11 & BT-11 & 3.8 & 89 & 32.4 & 4.5 & Acceptable appearance \\
\hline \multicolumn{7}{|c|}{$\begin{array}{c}\mathrm{d}=12 \mathrm{~mm}, \mathrm{D}=24 \mathrm{~mm} \\
(D=2 \mathrm{~d})\end{array}$} \\
\hline Test 12 & BT-12 & -------- & ------ & -------- & ------ & Open tunnel defect \\
\hline Test 13 & BT-13 & -------- & ------- & -------- & ------ & Cutting defect \\
\hline Test 14 & BT-14 & -------- & ------- & -------- & ------ & Cutting defect \\
\hline Test 15 & BT-15 & -------- & ------- & -------- & ------ & Cutting defect \\
\hline Test 16 & BT-16 & -------- & ------- & -------- & ------ & Cutting defect \\
\hline \multicolumn{7}{|c|}{$\begin{array}{c}\mathrm{d}=8,10 \text { and } 12 \mathrm{~mm} \text { (respectively) } \\
(\mathrm{D}=2.5 \mathrm{~d})\end{array}$} \\
\hline Test 17 & BT-17 & 5.57 & 140 & 47.5 & 5.75 & Acceptable appearance \\
\hline Test 18 & BT-18 & 4.3 & 106 & 36 & 4.7 & Acceptable appearance \\
\hline Test 19 & BT-19 & 3.88 & 100 & 33.9 & 5.1 & Acceptable appearance \\
\hline \multicolumn{7}{|c|}{$\begin{array}{c}\mathrm{d}=8 \mathrm{~mm}, \mathrm{D}=24 \mathrm{~mm} \\
(\mathrm{D}=3 \mathrm{~d})\end{array}$} \\
\hline Test 20 & BT-20 & 6.1 & 193 & 65.4 & 5.7 & Acceptable appearance \\
\hline Test 21 & BT-21 & -------- & ------- & --------- & ------ & Incomplete \\
\hline Test 22 & BT-22 & -------- & ------- & --------- & ------ & Flash (scraping) \\
\hline Test 23 & BT-23 & 5.45 & 133 & 45.1 & 5.1 & Acceptable appearance \\
\hline
\end{tabular}

b) The visual analysis denotes that the gap of the bobbin tool effects on the welded appearance. When the gap was bigger than the thickness of the substrate, there were incomplete joints and voids because of lack of strength in forging (thrust load). When the gap was lower than thickness, the edge of the shoulder scraped very thin layer of the surface of the substrate that leaded to produce an excessive flash and reduce the thickness of the plate. Consequently, the gap between shoulders must be equal to the thickness of the work-piece because it is the one with superior properties, which is harmonious with other study [4, 25].

c) In general, the bobbin tool (TB-10) created a good weld joint compared to that was produced by (TB-5). The reason of this is the tool (TB-10) had smaller dimensions than (TB-10). The reduction of strength is supposed to be on account of the amount of area (volume of material sweeping) that was influenced via the bobbin tool during welding process [26]. This interpretation applies to others tools.

d) The design of shoulders influences the generation of heat [26]. For the thickness of plate as used in this investigation, the needed heat generation could readily be taken out by the two sides of the bobbin tool features. Shoulder diameter has significant effect to improve the welding zone properties. The swell in the diameter of the shoulder means the growing of the friction area and thus increases the heat generated. Large amount of heat input is desired to break the grain boundary in transverse the welding through the work-piece [8]. The tunnel flaw at sample (TB-10) is elucidated that the reduced zone of provided heat via the smaller shoulder diamete probably resulted in premature solidification of the welding zone. The premature solidification and the tool dimension and 
its influence on the flow stress stated in [27,28, and 29]. The above reason explains the results of welding obtained from (TB-10) and (TB-23), see figure (10).
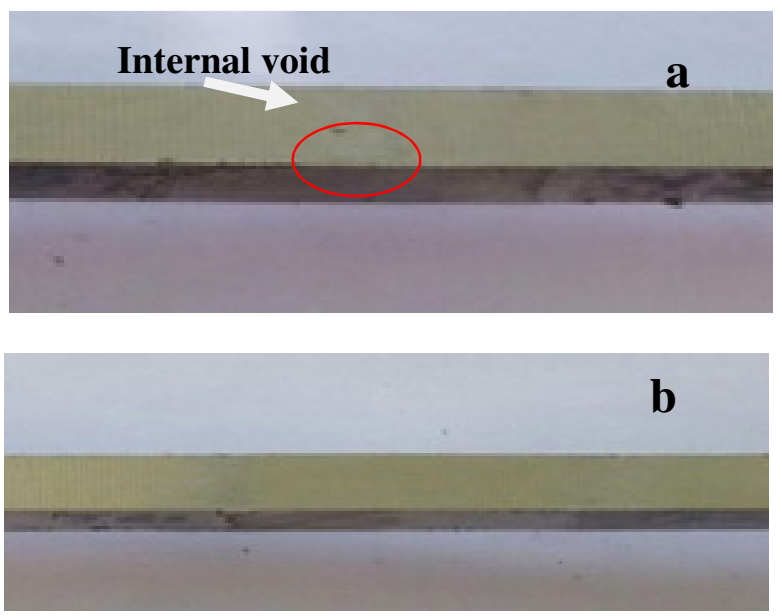

Fig. 10. a) Internal void (BT-10), b) Perfect crosssection welded zone (BT-23).

\section{Conclusions}

The overall aim of this investigation was to better comprehend the influence of tool geometry (features and dimensions) on the weld joint quality and select the best tool design for bobbin kind friction stir welding. So, from the present wok, the followings can be concluded:

1- Straight cylindrical probe with four flats created a free defect weld joint for the used thin substrate aluminum alloy 6061-T6 with superior mechanical properties (elongation, ultimate tensile strength and maximum bending force), resulting in a preferable bobbin tool design in the present investigation.

2- The dimensions of the bobbin tool (shoulders and pin) have a significant effect on the welding quality.

3- For the best bobbin tool design, the internal diameter of the pin is nearly similar to the substrate thickness, and the shoulder diameter should be three times the pin diameter.

4- The gap between the tool shoulders must be equal to substrate thickness.

5- The distance between tool shoulders can be adjusted to insert a useful compression influence, hence vertical flow movement.

6- The effects of stirring consisting of horizontal and vertical flow movements are significant to generate good weld quality.

\section{References}

[1] Kumbhar N. T., and Bhanumurthy K., "Friction stir welding of Al 6061 alloy", Asian J. Exp. Sci., Vol. 22, 2008 pp. 63-74.

[2] Mishra R. S., Ma Z. Y., "Friction stir welding and processing", Materials Science and Engineering R 50 (2005) pp. 1-78.

[3] W. M. Thomas, E. D. Nicholas, M.G. Needham, and D. J. Templesmith, "Friction Stir Butt Welding", International Patent Application PCT/GB92/02203, GB Patent Application 9125978.8, US Patent 5.460.317, 1991.

[4] Mohammad K. Sued and Dirk J. Pons, "Dynamic Interaction between Machine, Tool, and Substrate in Bobbin Friction Stir Welding", International Journal of Manufacturing Engineering Vol. 2016, Article ID 8697453, 14 pages.

[5] R. S. Mishra P. S. De and N. Kumar, "Friction Stir Welding and Processing Science and Engineering”, Springer, 2014.

[6] P. L. Threadgill, M. M. Z Ahmed, J. P. Martin, J. G. Perrett and B. P. Wynne, "The use of bobbin tools for friction stir welding of aluminum alloys", Materials Science Forum Vols. 638-642 (2010) pp. 1179-1184.

[7] T. Neumann, R. Zettler, P. Vilaca, J. F. dos Santos, and L. Quintino, "Analysis of selfreacting friction stir welds in a 2024-T351 alloy", Friction Stir Welding and Processing IV, pp. 55-72, 2007.

[8] M. K. Sued, D. Pons, J. Lavroff, and E. H. Wong, "Design features for bobbin friction stir welding tools: Development of a conceptual model linking the underlying physics to the production process", Materials and Design 54 (2014) pp. 632-643.

[9] W. M. Thomas, C. S. Wiesner, D. J. Marks, and D. G. Staines, "Conventional and bobbin friction stir welding of $12 \%$ chromium alloy steel using composite refractory tool materials", Science and Technology of Welding and Joining, Vol. 14, pp. 247-53, 2009.

[10] W. Thomas and C. S. Wiesner, "Recent Developments of FSW Technologies: Evaluation of Root Defects, Composite Refractory Tools for Steel joining and OnePass Welding of Thick Sections Using SelfReacting Bobbin Tools", In Trends in Welding Research, Proceedings of the 8th International Conference, 2009.

[11] J. C. Hou, H. J. Liu, and Y. Q. Zhao, "Influence of rotational speed on microstructures and mechanical properties of 6061-T6 aluminum alloy joints fabricated by 
self-reacting friction stir welding tool". International Journal of Advanced Manufacturing technology, July, 2014 73, pp. 1073-1079.

[12] H. J. Liu, J. C. Hou, and H. Guo, "Effect of welding speed on microstructure and mechanical properties of self-reacting friction stir welded 6061-T6 aluminum alloy", Material and Design 50 (2013) pp. 872-878.

[13] W. Y. Li, T. Fu, L. Hutsch, J. Hilgert, F. F. Wang, J. F. Santos and N. Huber, "Effect of rotational speed on microstructure and mechanical properties of bobbin-tool frictionstir welded Mg AZ31", Material and Design 64 (2014) pp. 714-720.

[14] L Zhou, G. H. Li, C. L. Liu, J. Wang, Y. X. Huang and J. C. Feng, "Effect of rotational speed on microstructure and mechanical properties of self-reacting friction stir welded $\mathrm{Al}-\mathrm{Mg}-\mathrm{Si}$ alloy", International Journal of Advanced Manufacturing technology, August, 2016.

[15] F. F. Wang, W. Y. Li, J. Shen, S. Y. Hu and J. F. Santos, Effect of tool rotational speed on microstructure and mechanical properties of bobbin friction stir welding of Al-Li alloy. Material and Design 86 (2015) pp. 933-940.

[16] Standard Specification for Aluminum and Aluminum Alloy ASTM Sheet and Plate, ASTM B209, 2004.

[17] Akos Meilinger, and Imre Torok, "The importance of friction stir welding tool. Production Processes and Systems". Vol. 6. (2013) No. 1, pp. 25-34.

[18] Heat treatment of Tool steels, Heat Treating, ASM, Vol.4, 1991.

[19] Yan Guanghua, Huang Xinmin, Wang Yanqing, Qin Xingguo, Yang Ming, Chu Zuoming and Jin Kang, "Effects of heat treatment on mechanical properties of $\mathrm{H} 13$ steel", Metal Science and Heat Treatment, Vol. 52, 2010, pp. 393-396.

[20] Sameer S. Chaudhary and Kaushal H. Bhavsar, "A review of Bobbin Tool Friction Stir Welding (FSW) Process", International Journal of Science Technology \& Engineering, Vol. 2, April, 2016, pp. 630-633.
[21] J. C. McClure, E. Coronado, S. Aloor, B. Nowak, L. M. Murr, and A.C. Nunes, Jr., "Effect of pin tool shape on metal flow during friction stir welding", In: Trends in Welding Research, Proceedings, 2003, pp. 257-261.

[22] Y.H. Zhao, Lin S. Wul, and F. X. Qu, "The influence of pin geometry on bonding and mechanical properties in friction stir weld 2014 Al alloy", Material Letters, Vol. 59, October 2005, pp. 2948-2952.

[23] S. J. Vijay and N. Murugan, "Influence of tool pin profile on the metallurgical and mechanical properties of friction stir welded Al-10 wt. \% TiB2 metal matrix composite", Material and Design, Vol. 31, August, 2010, pp. 3585-3589.

[24] amshidi Aval H., Serajzadeh S, and Kokabi A. H., "The influence of tool geometry on the thermo-mechanical and microstructural behavior in friction stir welding of AA5086. In: Proceedings of the institution of mechanical engineers, part c". Journal of Mechanical Engineering Science, Vol. 225, 2011. pp. 1-16.

[25] Eladio Amaro Camacho Andrade, "Development of the Bobbin-Tool for Friction Stir Welding Characterization and analysis of aluminum alloy processed AA 6061-T4", Institute Superior Technical, Lisbon, Portugal, 2010.

[26] A. Arora, A. De and T. Debroy,"Toward optimum friction stir welding tool shoulder diameter", Scripta Materialia, Vol. 64, January, 2011, pp. 9-12.

[27] Elangovan K, Balasubramanian V. Influences of tool pin profile and tool shoulder diameter on the formation of friction stir processing zone in AA6061 aluminum alloy. Mater Des 2008;29:362-73.

[28] Colligan KJ, Mishra RS. A conceptual model for the process variables related to heat generation in friction stir welding of aluminum. Scripta Mater 2008;58:327-31.

[29] Padmanaban G, Balasubramanian V. Selection of FSW tool pin profile, shoulder diameter and material for joining AZ31B magnesium alloy - an experimental approach. Mater Des 2009; 30:2647-56. 


\title{
دراسة تأثير تصميم عدة اللحام بالخلط الإتكاكي نوع (Bobbin) على الخواص الميكانيكية (6061-T6) لسبيكة المنيوم)
}

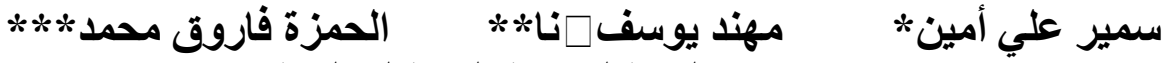

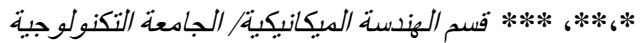 \\ alrabiee2002@yahoo.com البريد الالكتروني \\ mohannad_hanna@yahoo.com: البريد الالكتروني: ** الإكتروني \\ alhamza88f@yahoo.com البريد الإكتروني :**** الإنئ
}

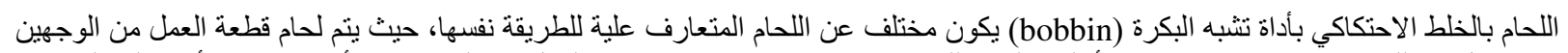

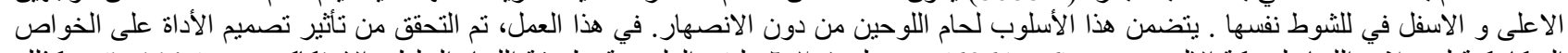

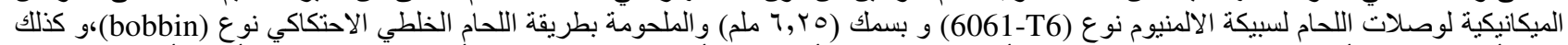

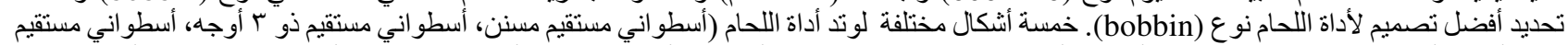

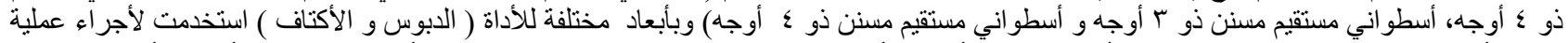

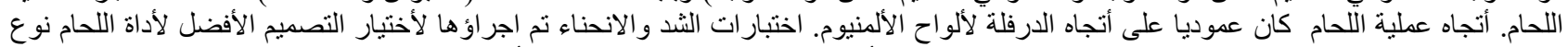

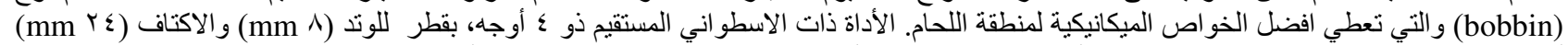

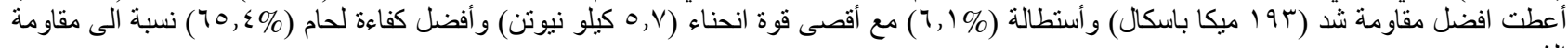

